\title{
The social network of adolescents who need special health care
}

\author{
Rede social de adolescentes que necessitam de atenção especial à saúde \\ La red social de los adolescentes que necesitan una atención especial a la salud
}

\section{Andressa da Silveira' \\ ORCID: 0000-0002-4182-4714 \\ Eliane Tatsch Neves' \\ ORCID: 0000-0002-1559-9533}

'Universidade Federal de Santa Maria. Santa Maria-RS, Brasil.

How to cite this article: Silveira A, Neves ET. The social network of adolescents who need special health care. Rev Bras Enferm. 2019;72(2):442-9. doi: http://dx.doi.org/10.1590/0034-7167-2018-0543

\section{Corresponding Author:}

Andressa da Silveira

E-mail: andressadasilveira@gmail.com

Submitted: 07-01-2018

Approved: 09-09-2018

\begin{abstract}
Objective: To describe the social network of adolescents who need special health care. Method: A qualitative, descriptive and exploratory study conducted between 2016 and 2017 in the pediatric outpatient clinic of a teaching hospital in southern Brazil. Thirty-five semi-structured interviews were conducted with adolescents between 12 and 18 years of age, followed by the construction of genograms and ecomaps. After transcription, the enunciations were subjected to Pêcheux's method of discourse analysis. Results: The institutional network consists of health services, schools and religious entities, as well as adolescents' families and friends. In the family network, women family members - such as mothers, grandmothers and aunts-have a special role. Final Consideration: The adolescents' social network is composed of institutional and family circles. In the view of adolescents, the tertiary service is more capable of solving their problems, and for this reason used the most. In order to ensure these adolescents access to and continuity of care, the articulation between health policies and health services is suggested.
\end{abstract}

Descriptors: Adolescent; Chronic Disease; Social Support; Health Services; Comprehensive Health Care.

\section{RESUMO}

Objetivo: Descrever a rede social de adolescentes que necessitam de atenção especial à saúde. Método: Estudo qualitativo, descritivo e exploratório realizado entre 2016 e 2017 no ambulatório pediátrico de um hospital de ensino no sul do Brasil. Foram realizadas 35 entrevistas semiestruturadas com adolescentes entre 12 a 18 anos de idade, seguidas pela construção de genogramas e ecomapas. Após a dupla transcrição, as enunciações foram submetidas à análise de discurso pechetiana. Resultados: A rede institucional é composta por serviços de saúde, escolas e entidades religiosas, além de familiares e amigos dos adolescentes. Na rede familiar, as mulheres são enaltecidas, representadas pelas mães, avós e tias. Considerações Finais: A rede social dos adolescentes é composta pelos círculos institucional e familiar. Na ótica dos adolescentes, o serviço terciário é mais resolutivo e por isso é o mais utilizado. Sugere-se articular as políticas e os serviços de saúde para o acesso e continuidade do cuidado desses adolescentes.

Descritores: Adolescente; Doença Crônica; Apoio Social; Serviços de Saúde; Atenção Integral à Saúde.

\section{RESUMEN}

Objetivo: Describir la red social de los adolescentes que necesitan una atención especial a la salud. Método: Estudio cualitativo, descriptivo y exploratorio, realizado entre 2016 y 2017 en la clínica pediátrica de un hospital escuela en la región sur de Brasil. Se realizaron 35 entrevistas semiestructuradas con adolescentes de 12 a 18 años de edad, y después se elaboraron genogramas y ecomapas. Después de la doble transcripción, se sometieron los relatos a análisis de discurso pecheutiano. Resultados: En la red institucional constan de servicios de salud, escuelas y organismos religiosos, así como de familiares y amigos de los adolescentes. En la red de la familia, se elogian a las mujeres, representadas por las madres, las abuelas y las tías. Consideraciones Finales: La red social de los adolescentes se compone de círculos institucionales y familiares. En la perspectiva de los adolescentes, el servicio terciario es más resolutivo, por lo tanto, es lo más utilizado. Se recomienda articular las políticas con los servicios de salud para que se oferte a estos adolescentes el acceso a la salud y la continuidad del cuidado.

Descriptores: Adolescente; Enfermedad Crónica; Apoyo Social; Servicios de Salud; Atención Integral de Salud. 


\section{INTRODUCTION}

Children and adolescents who need special health care (CRIANES) are defined as those who demand care beyond the required by children and adolescents in general. CRIANES live with chronic health conditions, or have some type of disability or limitation; the latter are attributed different designations that refer to special health care needs while avoiding their stigmatization ${ }^{(1,2)}$.

CRIANES' health care needs are divided into six categories: developmental (psychomotor and social rehabilitation); technological (relying on some kind of body-implanted technology); drugs (substance dependence); modified daily life activities (requiring adaptations to carry out common day-to-day tasks); mixed demands (more than one type of demand for associated care); and clinically complex care (a combination of all of the above, including the management of life support technologies) ${ }^{(3)}$.

In the United States, the CRIANES group is comprised of 14.6 million children and adolescents; in Chile, $12.9 \%$ of the children and adolescents who present some type of functional limitation or disability are considered CRIANES ${ }^{(4,5)}$.

In Brazil there are no official numbers on adolescents living with special health care needs; however, their reliance on public health services is known. In the pediatric outpatient clinic of the Hospital Universitário de Santa Maria (HUSM), a referral service for adolescents in the central region of Rio Grande do Sul, there is an average of 97 monthly consultations involving this population.

Regarding the matter of special health care demands, it should be emphasized that this population has different medical complexity, family burdens and health needs when compared to other children and adolescents, besides being more susceptible to health inequalities, requiring differentiated care and access to a range of health services ${ }^{(6)}$.

Institutional and family networks are part of these adolescents' overall social network, the first corresponding to health services and the second to family ties ${ }^{(7)}$. The CRIANES social network is formed by a collective structure, with strong and weak links of dependency or autonomy. It can be integrated by institutions, socialization groups and virtual networks, which contribute positively to coping with chronic illness ${ }^{(8,9)}$.

In order to meet these children's and adolescents' care demands, a network of continuous care, permeated by responsibility, acceptance and commitment in the planning of actions, is indispensable ${ }^{(10)}$.

In this sense, it is fundamental to look at this group's adolescent social network, considering that these individuals have health care requirements beyond other adolescents in their age group. In view of the above, our guiding question was: how is the social network of adolescents who need special health care configured?

\section{OBJECTIVE}

To describe the social network of adolescents who need special health care.

\section{METHODS}

\section{Ethical aspects}

The study followed the recommendations of Resolution No. $466 / 2012$, of the National Health Council, and was conducted in accordance to its ethical standards. It was authorized by the Research Ethics Committee of the Federal University of Santa Maria. For the interviews, a consent term was signed by adolescents, and a free and informed consent form was signed by relatives/companions. In order to preserve participants'identities, the alphanumeric code "A" was used to refer to adolescents, followed by ordinal numbers in the sequence in which the interviews were conducted.

\section{Type of study}

A qualitative, descriptive and exploratory study carried out from the second half of 2016 until the first half of 2017.

\section{Scenario of the study}

The study was carried out in the pediatric outpatient clinic of a teaching hospital in the south of Brazil. The hospital is a reference of the Unified Health System (SUS) for the central region of Rio Grande do Sul.

\section{Data source}

Participant selection was made through the preliminary analysis of adolescents' medical records, carried out in the shift previous to the consultation, in order to identify if they met the checklist for the identification of CRIANES ${ }^{(11)}$ members. This procedure was followed by the invitation to participate in the survey.

\section{Data collection}

Data collection was developed through the semi-structured interview, recorded in digital media and mediated by the construction of a genogram and an ecomap, both guided by the adolescents. The interviews were conducted by the principal researcher with the support of a research assistant, in private, and had an average duration of 20 minutes.

\section{Study participants}

The sample was comprised of 35 adolescents-selected through purposive sampling ${ }^{(11)-}$ between 12 and 18 years of age who were aware of their own health demands, and able to verbalize them. Adolescents were allowed to choose if they wanted family or companions present during the interview. Everyone opted for family or companions to stay. However, family interventions were disregarded because they were not the object of study.

\section{Data analysis}

The enunciations underwent double transcription and were subjected to Pêcheux's method of discourse analysis (DA). The theoretical-analytical framework of DA allows for a reflection on the meanings of produced texts. By viewing language as interpretative, DA sheds light on interdiscourse, discursive memory, meaning effects, and ideology. As such, language has a polysemous and paraphrastic character: the discourse enunciator presents a new knowledge, with many voices conferring meaning to what was enunciated. The discourse is organized by (and anchored in) the 
conditions of production. Its use in a given context constitutes new meanings and reconstitutes old ones, mediated by the ideological perspective of the enunciator ${ }^{(12)}$.

In DA, three stages have to be considered. 1) Passage from the linguistic surface to the discursive object. The audio of the interviews was listened to, and the horizontal reading of the text (seen as a discourse in movement) was carried out. This stage represents the moment when linguistic materiality is constituted. 2) Passage from the discursive object to the discursive process. In this stage, analytical tables are built and a vertical reading is performed. This amounts to discursive formation. 3) Analysis of the discursive process, where ideological formation is identified and the units of meaning or themes that generate the analysis are composed ${ }^{(12)}$.

The genogram allowed us to present the internal composition of the families, evidencing the care nodes of adolescents with special health care needs. Meanwhile, the ecomap presents a general perspective of the links between adolescents and the social network. Solid lines represent strong bonds, dotted lines represent weak bonds, thin and interrupted lines point to stressful relations, and the arrows show the directions of established flows ${ }^{(13)}$.

\section{RESULTS}

The discourse of the studied adolescents shows that they go to school, have friends, play sports, dance, work, and help the family. Their discursive medium reveals that they seek sources of leisure and socialization, such as games, dance, music, reading and internet. The metaphors and polysemic contents present in their discourses point that they try to live their adolescences naturally.

Yeah. Sometimes I listen to music, or play with my six-year-old niece. And I dance too! And I talk to people. (A1)

Then I come back from school... And then I havelunch, brush myteeth, then ... Watch TV, drink coffee, do the themes, then watch TV again, and then at night, at dinner time, have dinner, brush my teeth, and then watch TV somemore, and then go to sleep. Oh, and I play with my cell phone... [laughs] and then I go to bed! (A2)

My day moves fast! I go to class in the mornings, and during the break l eat [a snack] ... I play video games and I go to my friend's house! (A3)

Oh... I go out, like, sometimes! ... Yes, to visit my grandmother, watch television, sleep during the afternoon, eat as well! ... I like the internet! (A5)

Sometimes I go out [of the farm house] and sometimes I stay at home, tidying it up. And in the afternoon I have class ... We do dance rehearsals twice a week. (A8)

Igo to school; atschool I have asnack around 9or $10 o^{\prime}$ lock... Igo [to computer class] and browse the internet [laughs] ... I am part of the [name of school group] and also the Guardianship Council ... Ialso do computerstuff, soccer and design. (A10)

... I mostly play soccer, once a week, in school ... And I ride my bike every day! (A11)
I wake up in the morning by five o'clock, then I go to class, and arrive at around one o'clock, and then I help my father at home [at the farm] until about six o'clock in the afternoon. (A18)

I wake up, go to class ... Then have lunch at home, then sleep all afternoon [laughs] —every now and then, 'cause there are afternoons when I have training! I play futsal and volleyball. ... I have volleyball and futsal training twice a week ... Every week, almost every day. (A20)

... Yeah, I play soccer and volleyball! I do [these activities] twice a week. (A26)

In order to present the extensive social configuration of the adolescent with special health care needs, we employed two imaging tools: the genogram and the ecomap. Figure 1 shows A8's genogram and ecomap. This teenager lives with parents and siblings - a social network comprised of the institutional and family networks, segmented into health, school, church, dance school, and family. The adolescent included the family's cat in her ecomap, a pet with which she has a strong bond.

Adolescents had large social networks, indicating that health demands did not prevent them from experiencing social coexistence. The metaphorical meaning expressed in the phrase "everybody knows" appears in the discursive formation of these adolescents, emphasizing that, for them, the demands of health care are not impeding factors for social interaction. On the contrary, when they say they have special health care demands, they emphasize their need for being treated naturally.

Oh, see! Everyone knows ... the neighbors, friends, school! (A9)

Yes, everybody knows! (A10)

Yeah. Everybody knows! (A29)

Oh, everyone knows! ... (A30)

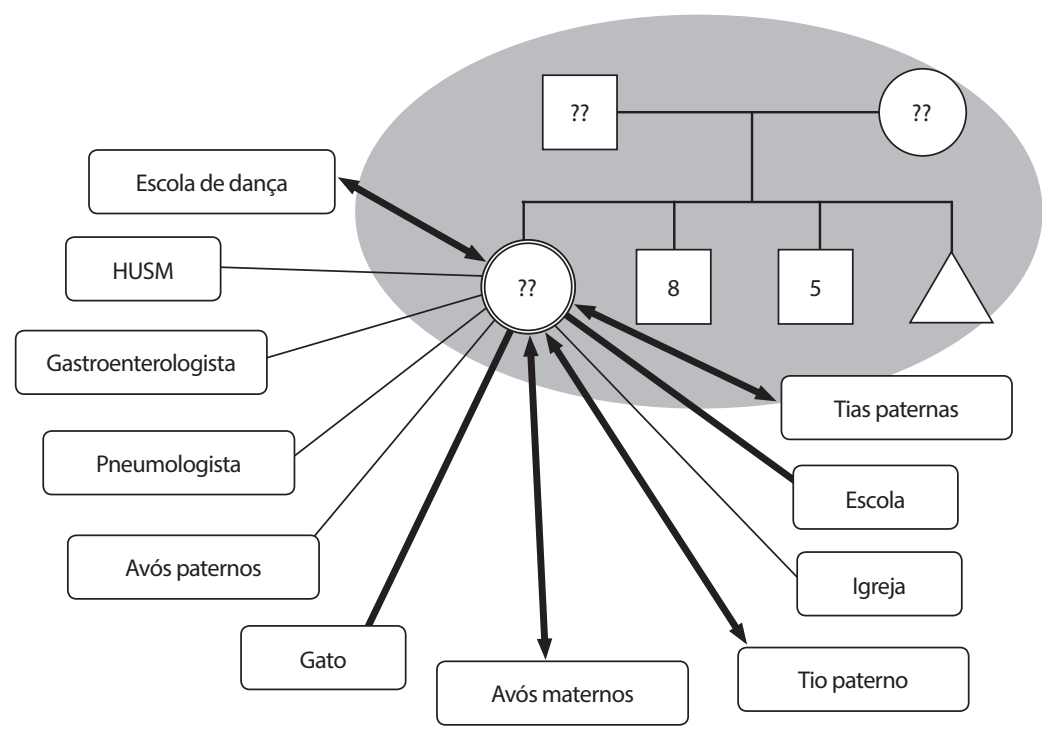

Figure 1 - A8's genogram and ecomap 
Everybody knows! Family, school, friends ... But only family provides support. (A32)

Figure 2 shows A17's social configuration. Although the teenager had a father, mother and siblings, she was taken care of by her aunts and lived with one of them. In addition, she had an expanded institutional network, composed of medical specialties, psychologist and pediatric outpatient clinic.

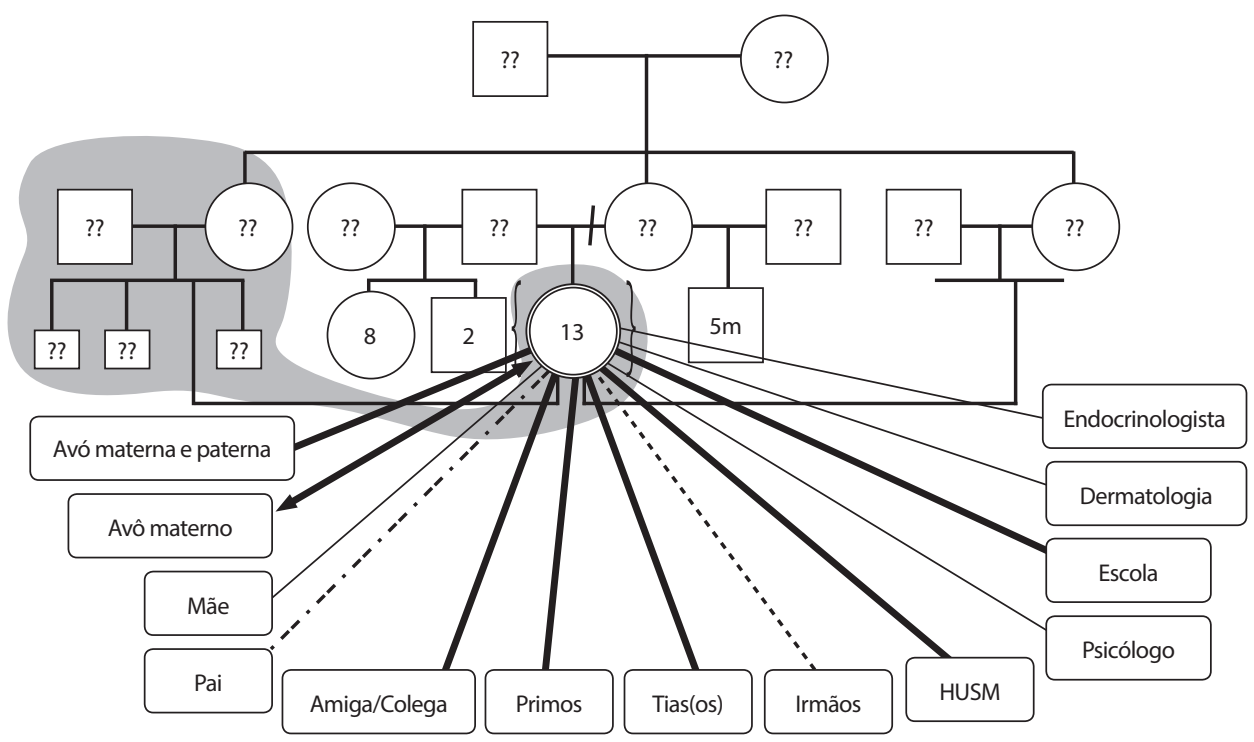

HUSM: University Hospital of Santa Maria

Figure 2 - A17's genogram and ecomap

Interdiscourse and discursive memory are present since childhood, when the child is taught to see health professionals' interventions as punishment. The metaphorical meaning of the enunciation "the doctors were so cruel" denotes the feeling of the adolescent in face of a period of hospitalization. This points to the need to reflect on the strategies used for health care of hospitalized adolescents living with chronic conditions.

The doctors were so cruel! Yes, I was [hospitalized] for five days! [Three days in the ICU] plus two days in the [private] room! (A10)

I think there have been more than 10 [hospitalizations] so far, much more! Yeah, I think there have been more! Much more! And nine surgeries! (A24)

Yeah! Two [hospitalizations], I think. Or three, something like that. (A25)

Regarding the use of health services, some adolescents used only the pediatric outpatient clinic. For them, the primary care system failed to provide a solution, and therefore they chose the hospital service as their primary means of access. Other adolescents talked about their lives'trajectories, and other health services they accessed.
All you really need is [a health center ] ... At the hospital and at the nursing post I had a lot of help! They were very good! There in [city of origin] there isn't a lot of assistance... Since I have no follow-up with the doctor there, they do not want to give me much assistance [at the health center]. (A10)

Igo to the village's health center! Once a month, I think! Or two! (A13)

Oh, just here! [at the University Hospital]. When I'm in the city I'll eventually go to a health center or something. I consult with the pulmonologist here [at the University Hospital] ... There [in the city of origin] they [doctors at the health center] knew [it was asthma]! (A20)

I've been coming here for 14 years, a long time. Everyone knows me here. Here everybody [from the team] knows me! (A24)

Usually we go to the emergency room there [in the city of origin] And when we are here [in the University Hospital], we ask the doctor [pulmonologist] for assistance. (A31)

Members of CREANES tend to have a larger institutional network. For some adolescents this network goes beyond outpatient services, extending even to other locations. Figure 3 shows A14's genogram and ecomap. This particular adolescent had an expanded health care network, including primary care, hospital and outpatient services, which reinforces that, for these adolescents, differentiated care is necessary (in comparison to other adolescents in their age group).

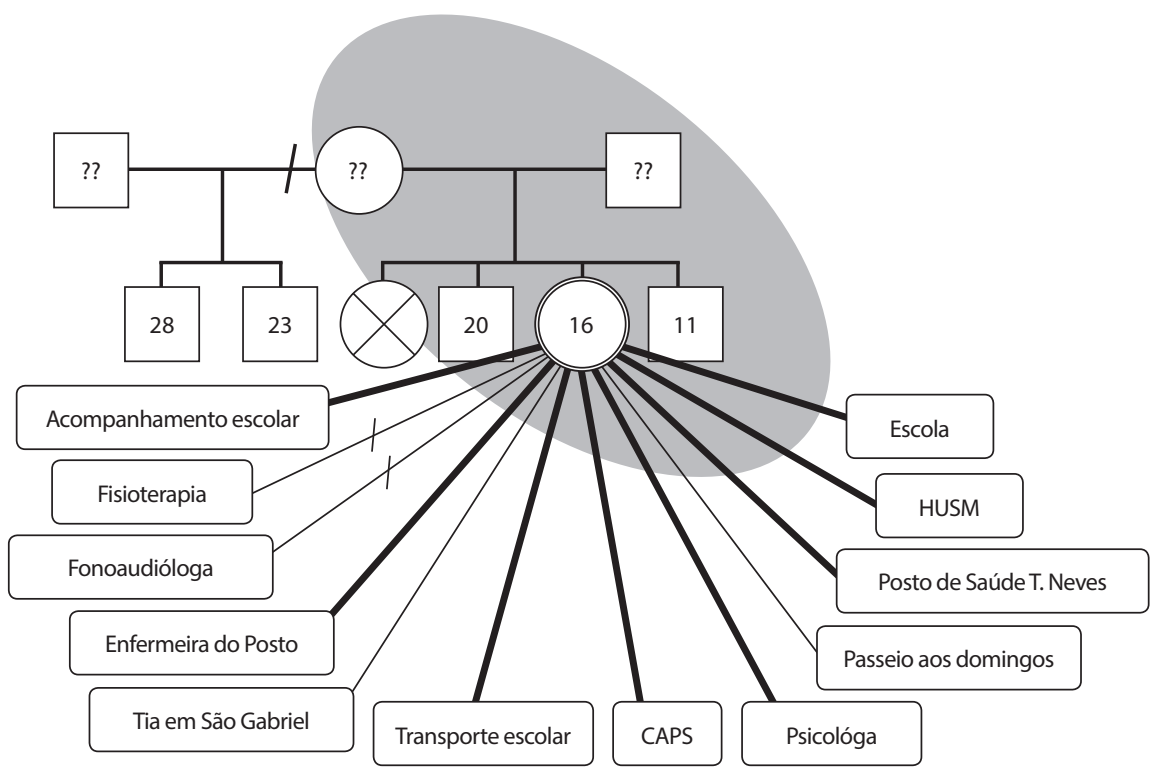

HUSM: University Hospital of Santa Maria;; CAPS: Center for Psychosocial Care; T. Neves: Tancredo Neves

Figure 3 - A14's genogram and ecomap 
In their discourse, the adolescents praised the health services they accessed and used. However, for some it is not possible to identify the point of onset of the chronic condition. Thus, the metaphors and polysemic meanings in their discourses revealed a lack of knowledge about when their diagnosis was discovered, especially for those whose special care demands began in childhood, and who were initially cared for by the family.

Only when I have some kind of accident! Then I go to the health center. ... I've been to a psychologist before, about 18 times... But, ah, it's boring! Bah! ... I dunno, since I was born, I think! [referring to medical history in the University Hospital]. (A3)

... I went to the nutritionist only in the beginning [of the diagnosis], only once! ... The nurses [taught me to apply] insulin ... No, I mean the nurses from [name of home city]! As soon as I left [hospitalization]! (A10)

I've been here [at the University Hospital clinic] for how long?! About two or three months ... Yes, that's all I do here [consultations with endocrinologist and nutritionist]. The nutritionist goes to my school! She goes every other day. (A11)

I just come here [to the University Hospital clinic]. [Otherwise,] only the psychologist ... Sure, the psychologist! I've visited about five times, I think ... Already! Since last year. (A17)

I think... two years. It's probably been two years [of visiting the endocrinologist]. (A19)

Only when I have a fever. When I'm sick I go to the health center. But I rarely get sick. I think I go to the health center, like, once a month. Yeah, because it's so hard for me to get sick! ... Once a month!(A26)

I guess... two and a half years. Since 2012, right? Yeah... about three years I think ... A nutritionist and a psychologist too! I have been going to the psychologist for like a month. (A29)

Yeah, it's been already ... The psychologist ... and the nutritionist too, I consulted with her about three times, during my hospitalization. (A30)

I started coming to the University Hospital I think a couple of years ago ... Sometimes I go to the health center ... and to the hospital only when I'm sick, I don't go straight to the health center! (A31)

Some adolescents recognized the church as a spiritual support that makes it possible to face the difficulties imposed by their health condition. This is seen in the polysemic character of the expressions "I like going to church alone,"'because I really wanted to" and "church helps." However, the spiritual approach was not enough for all adolescents, as $\mathrm{A} 1$ reveals in this passage:

Oh, it's all about the prayer... (A1)

I enjoy it! I like to go to church alone ... And listening to music, we listen to music there [in the church]! (A15)
... I go to the catechesis every Saturday. I go because I really want to! (A19)

There's the youth group, so you have to go to their meetings. There are the Olympics [organized by the Catholic Church] twice a year! Two, three times a year. ... I do go [to Mass]. (A18)

The Church helps! ... It was very difficult, very difficult! I thought there was no coming back ... But since I have lots of faith ... I never gave up, I was firm in my faith! I was going to go through it! (A24)

The search for spirituality as an emotional support and source of strength helps in the process of socialization. A2's genogram and ecomap present the church and the youth group as part of the adolescent's social network.

In their ideological affiliation, adolescents show that their demands for care do not prevent them from coexisting socially with other adolescents, although these demands are fundamental for their survival. The discursive constructions of adolescents give meaning to a social network comprised of health, institutional, social, and family segments. The diversity of accessed services indicates that these adolescents demand care beyond other adolescents in their age group. The knowledge, or lack thereof, about their health condition, reiterates the importance of establishing a dialogue with the adolescent, enabling their participation in the care process. Their reliance on spirituality reveals that not only socialization, but also emotional support is needed.

\section{DISCUSSION}

The enunciations of the research participants present, in their own language, a discursive memory related to the need to overcome the limitations imposed by the demands of special health 
care. Their discourse is marked by the desire of belonging to the social network by identifying with its groups, and also the desire of not being seen as adolescents who require special care. Thus, we perceive a discourse based on the ideology of becoming more, via the possibilities of the adolescent's universe.

A study carried out in a Health Center of Minas Gerais in 2015 pointed out that the adolescent needs to feel equal to other adolescents. This demand is even greater within groups of friends-since these groups are places for sharing experiences, for the formation of identity and for recognition. The chronic condition may negatively impact these relationships due to the restrictions imposed by the disease, which also have an effect on the adolescent's self-image ${ }^{(14)}$.

The discursive fragments of adolescents refer to the use of the Internet as a tool for their daily activities and also for socialization. This finding was also observed in a study carried out with 482 adolescent students from Rio Grande do Sul. The study showed that the adolescents frequently maintain online relationships. Although these relationships do not provide strong bonds, they can be considered an important form of social contact. The Internet is a complementary tool of social interaction, since in adolescence, peer relationships are fundamental for healthy development. However, the authors point out that online social networks should not replace face-to-face relationships ${ }^{(15)}$.

Their discursive and ideological formation, grounded in transcendence and possibilities, praise fundamental movements for the adolescent, among them socialization, empathy and the need to establish relationships. Adolescence is marked by the acquisition of social skills, and adolescents are extremely sensitive to messages of sympathy coming from their peers ${ }^{(14)}$. In this way, it is essential to support mechanisms that address health and well-being, reducing social disadvantage and optimizing the chances for the fruition of life ${ }^{(16)}$.

Health care is a marked feature of adolescent discourse. The coordination of this care is a complex process that needs to be addressed in the community during the hospitalization phase and after hospital discharge, considering the different demands that these moments present. This converges with the study carried out in Rio Grande do Sul, which confirms the need for assistance to these children, adolescents and their families, starting from hospital discharge, in favor of empowerment through interdisciplinary care networks ${ }^{(8,17)}$.

The discursive formation seen here points to the diversity of services accessed, with emphasis on the hospital service at the outpatient level, emergency care and the health center. The adolescents studied end up accessing the tertiary level primarily because they believe that primary health care $(\mathrm{PHC})$ is not always able to provide a solution. In Rio Grande do Sul, this population preferably accesses places that provide services at the tertiary level ${ }^{(8)}$.

This reality is also confirmed in Rio de Janeiro, where the hospital service is the first level of access by CRIANES $^{(3)}$, evidencing their difficulties of using health services for continued treatment after hospital discharge. In the United States, $48.8 \%$ of the families of these children and adolescents reported difficulties in accessing medical services and $31 \%$ in accessing other services ${ }^{(18)}$. This converges with the problem of CRIANES' access to care in the community ${ }^{(19)}$. Improving the health of people living with chronic conditions requires transforming an essentially fragmented, reactive and episodic health care system to respond to health needs in a proactive, integrated and continuous way, with emphasis on individuals and their family, as well as the promotion and maintenance of health ${ }^{(20)}$.

Adolescents' discourse, genograms and ecomaps contained praise to the care networks. The restriction of children and adolescent social networks can overwhelm their participants. At the same time, extended networks may not be effective, since they may be premised on dealing with common problems by transferring responsibility over them, which leads to greater disengagement. We suggest that networks should have average sizes, limiting the issues presented by both reduced and expanded networks, and better distributing the activities and support they provide ${ }^{(21)}$.

Interdiscourse and discursive memory of adolescents are anchored in the challenges of care. A study carried out in Ceará with families of children and adolescents with myelomeningocele revealed that, after hospital discharge, arriving home generated changes in the family organization in the face of demands for care and social challenges, since the society discriminates people with special needs, offering few possibilities and limiting potentialities $^{(22)}$. It is imperative for the nurse to share the responsibilities of discharge coordination with other health professionals, constructing means to facilitate care, with autonomy, safety and quality ${ }^{(23)}$.

The need for transference and countertransference of care is highlighted as part of the integral care premise ${ }^{(3)}$. This view requires that health professionals be prepared to take full care of their patients through technology-backed accountability, which allows children, adolescents and families to remain firmly supported throughout the whole process ${ }^{(20,24)}$.

As for the spiritual support present in the adolescent's discourse, studies reveal that religious services function as a support network for CRIANES and their families ${ }^{(3,24)}$. A study conducted with adolescents from Rio Grande do Sul aiming to discuss the relationships between life satisfaction, family satisfaction, friendships and religiosity showed that $69.7 \%$ of adolescents reported having some religion, and that adolescents with higher rates of religiosity may present higher levels of life satisfaction and well-being ${ }^{(24)}$.

\section{Limitations of this study}

The limitations of this study are related to the fact that it was restricted to the pediatric outpatient clinic of a teaching hospital. This means that it can be expanded to other health scenarios, such as primary care.

\section{Contributions to the field of nursing}

A look at the social network of adolescents with special health care needs is of utmost importance, considering this group requires care beyond other adolescents in their age group. Rethinking the practice of health professionals in relation to this public is also crucial since, in in their discourse, the tertiary service appears as the most capable of solving their problems. It is important to point out that these adolescents need a multidisciplinary 
health care, able to open a path towards comprehensive care. There is urgent need for the elaboration of policies and health programs specific to this clientele, with emphasis on support and care networks, and the purveying of community spaces for the continuity of care.

\section{FINAL CONSIDERATIONS}

The discursive and ideological movement of the studied adolescents denotes that they seek to experience adolescence in a natural way, and aim to be seen from the lens of their potentialities, participating in diversified activities in the community and with their peers, and being continuously in search of social relations. Among activities that are part of their social network, school, games, sports, dance, going out with the friends and family, and the use of the Internet stand out.

Their discursive formation expressed the conformation of the institutional network, woven by the various health segments, such as hospital, emergency care, outpatient service and also a distinct network formed by school, church, dance school, family, friends and neighbors.
The pediatric outpatient clinic was highlighted as the main point of the health network, since for some adolescents, primary care was unable to solve their problems, encouraging them to seek the hospital service first. The genograms and ecomaps show that the institutional networks are extensive and comprised of several health professionals, which reinforces that, for these adolescents, the demands of care are broader than those required by other adolescents of the same age group.

Adolescents have strong family ties, with an emphasis on female figures represented by mothers, grandmothers and aunts. In addition, it is important for the family to know about their health demands, so that they are treated naturally.

The church stands out as a source of social support. For some, it symbolized the emotional support and strength to keep exercising their care and believing in their recovery, especially during moments of greater distress-primarily hospitalization.

In the adolescent's discourse, the tertiary service is most capable of solving their health issues and, therefore, the most used. The articulation of health policies and services is suggested, so that adolescents with special health care needs may have ensured continuity of care and access to care.

\section{REFERENCES}

1. Silveira A, Neves ET. [Political dimension to child and adolescent with special health needs care: a reflection]. Rev Enferm UFSM [Internet]. 2017[cited 2017 Nov 14];7(2):337-46. Available from: http://dx.doi.org/10.5902/2179769221976 Portuguese.

2. Matta GC, Morosini MVG. In Pereira IB, Lima JCF. Dicionário da educação profissional em saúde. 2a ed. Rio de Janeiro: EPSJV; 2008.

3. Cabral IE, Moraes JRMM. Family caregivers articulating the social network of a child with special health care needs. Rev Bras Enferm [Internet]. 2015 [cited 2018 Jun 25];68(6):1078-85. Available from: http://www.scielo.br/pdf/reben/v68n6/en_0034-7167-reben-68-06-1078.pdf

4. Child and adolescent health measurement initiative (CAHMI). Who are children with special health care needs [Internet]. 2012 [cited 2017 Aug 10]. Available from: http://www.childhealthdata.org/

5. Cano JCF, Calvo ML, Zamorac NR, Anguita MEA, La Paz MG, Yanez SB, et al. Modelo de atención y clasificación de niños y adolescentes con necesidades especiales de atención en salud - NANEAS: recomendaciones del Comité NANEAS de la Sociedad Chilena de Pediatría. Rev Chil Pediatr [Internet]. 2016 [cited 2017 Nov 7];87(3):224-32. Available from: https://scielo.conicyt.cl/pdf/rcp/v87n3/art14.pdf

6. Kuo D, Goudie A, Cohen E, Houtrow A, Agrawal R, Carle AC, et al. Inequities in health care needs for children with medical complexity. Health Affairs [Internet]. 2014 [cited 2018 Jun 24];33(12):2190-8. Available from: https://www.ncbi.nlm.nih.gov/pmc/articles/PMC4334319/

7. Zamberlan KC, Neves ET, Silveira A, Paula CC. The family care of children with special health care needs in the community context. Ciênc Cuid Saúde [Internet]. 2013 [cited 2018 Jun 24];12(2):290-7. Available from: http://periodicos.uem.br/ojs/index.php/CiencCuidSaude/article/ download/21758/pdf_14

8. Neves ET, Silveira A, Arrué AM, Pieszak GM, Zamberlan KC, Santos RP. Network of care of children with special health care needs. Texto Contexto Enferm [Internet]. 2015[cited 2017 Nov 14];24(2):399-406. Available from: http://www.scielo.br/pdf/tce/v24n2/0104-0707tce-24-02-00399.pdf

9. Silva SG, Melo TCM, Eleutério FR, de Faria PCS. Social and virtual support network for teenagers living with chronic disease: an integrative review. Aquichán [Internet]. 2015[cited 2018 Jun 25];15(1):60-74. Available from: http://www.scielo.org.co/pdf/aqui/v15n1/v15n1a07.pdf

10. Nóbrega VM, Silva MEA, Fernandes LTB, Viera CS, Reichert APS, Collet N. Chronic disease in childhood and adolescence: continuity of care in the health care network. Rev Esc Enferm USP [Internet]. 2017 [cited 2018 Jun 25];51:e03226. Available from: http://www.scielo.br/pdf/ reeusp/v51/1980-220X-reeusp-51-e03226.pdf

11. Arrué AM, Neves ET, Magnago TSBS, Cabral IE, Gama SGN, Hökerberg YHM. Tradução e adaptação do Children with Special Health Care Needs Screener para português do Brasil. Cad Saúde Pública [Internet]. 2016[cited 2018 May 18];32(6):e00130215. Available from: http:// www.scielo.br/pdf/csp/v32n6/1678-4464-csp-32-06-e00130215.pdf

12. Orlandi EP. Análise de Discurso: princípios e procedimentos. 12a. ed. Campinas: Pontes; 2015.

13. Wright LM, Leahey M. Enfermeiras e famílias: um guia para avaliação e intervenção na família. 5a. ed. São Paulo: Roca; 2012.

14. Silva LLT, Vecchia BP, Braga PP. [Adolescent in people with chronic disease: a comprehensive review]. Rev Baiana Enferm [Internet]. 2016 [cited 2017 Aug 20];30(2):1-9. Available from: https://portalseer.ufba.br/index.php/enfermagem/article/view/14281 Portuguese. 
15. Terroso LB, Argimon IIL. Dependência de internet e habilidades sociais em adolescentes. Estud Pesqui Psicol [Internet]. 2016[cited 2018 Jun 25];16(1):200-19. Available from: http://pepsic.bvsalud.org/pdf/epp/v16n1/v16n1a12.pdf

16. Houtrow A, Jones J, Ghandour R, Strickland B, Newacheck P. Participation of children with special health care needs in school and the community. Acad Pediatr [Internet]. 2012[cited 2018 Jun 25];12(4):326-34. Available from: https://www.ncbi.nlm.nih.gov/pmc/articles/ PMC4976484/

17. Zanello E, Calugi S, Rucci P, Pieri G, Vandini S, Faldella G, et al. Continuity of care in children with special healthcare needs: a qualitative study of family's perspectives. Ital J Pediatr [Internet]. 2015[cited 2018 Jun 24];8:41-7. Available from: https://www.ncbi.nlm.nih.gov/pmc/articles/ PMC4328636/

18. Kuo DZ, Cohen E, Agrawal R, Berry JG, Casey PH. A national profile of caregiver challenges among more medically complex children with special health care needs. Arch Pediatr Adolesc Med [Internet]. 2011 [cited 2018 Jun 25];165(11):1020-6. Available from: https://www.ncbi. nlm.nih.gov/pmc/articles/PMC3923457/

19. Rosen-Reynoso M, Porche MV, Kwan N, Bethell C, Thomas V, Robertson J, et al. Disparities in access to easy-to-use services for children with special health care needs. Matern Child Health J [Internet]. 2016[cited 2018 Jun 25];20(5):41-53. Available from: https://link.springer.com/ article/10.1007\%2Fs10995-015-1890-z

20. Mendes EV. O cuidado das condições crônicas na atenção primária à saúde: o imperativo da consolidação da estratégia da saúde da família. Brasília, DF: OPAS; 2012.

21. Nunes MR, Ferriani MGC, Malta DC, Oliveira WA, Silva MAI. Social network of adolescents under probation from the perspective of public health. Rev Bras Enferm [Internet]. 2016 [cited 2018 Jun 25]; 69(2):298-306. Available from: http://www.scielo.br/pdf/reben/v69n2/en_00347167-reben-69-02-0298.pdf

22. Figueiredo SV, Sousa ACC, Gomes ILV. Children with special health needs and family: implications for Nursing. Rev Bras Enferm [Internet]. 2016[cited 2018 Jun 25];69(1):88-95. Available from: http://www.scielo.br/pdf/reben/v69n1/en_0034-7167-reben-69-01-0088.pdf

23. Góes FGB, Cabral IE. Discourses on discharge care for children with special healthcare needs. Rev Bras Enferm [Internet]. 2017 [cited 2018 Jun 25];70(1):163-71. Available from: http://www.scielo.br/pdf/reben/v70n1/en_0034-7167-reben-70-01-0163.pdf

24. Silva DG, Giordani JP, Dell'aglio DD. Relations between life satisfaction, family and friendship satisfaction and religiosity in adolescence. Est Inter Psicol [Internet]. 2017[cited 2018 Jun 24];8(1):38-54. Available from: http://dx.doi.org/10.5433/2236-6407.2016v8n1p38 